Terr. Atmos. Ocean. Sci., Vol. 17, No. 4, 921-931, December 2006

\title{
Geochemical Study on Hydrocarbon Gases in Seafloor Sediments, Southwestern Offshore Taiwan - Implications in the Potential Occurrence of Gas Hydrates
}

\author{
Jung-Nan Oung ${ }^{1, *}$, Chen-Ying Lee ${ }^{2}$, Chao-Shing Lee ${ }^{2}$, and Cheng-Lung Kuo ${ }^{3}$
}

(Manuscript received 27 October 2005, in final form 28 April 2006)

\begin{abstract}
Seafloor sediment samples collected from southwestern offshore Taiwan have been analyzed for hydrocarbon gases resident in samples by using the technique of headspace gas analysis. The results reveal that the gas content is in tens to thousands ppm (vol. in wet sediments). Both microbial gas (usually called biogenic gas) dominated with methane and thermogenic gas containing $\mathrm{C}_{2}^{+}$hydrocarbons were detected, inferring that the gases involved in the potential gas hydrate occurrence in the study area may have multiple origins. The microbial gas generated by methanogenic archaea in immature sediments is more widely distributed than thermogenic gas generated in sediments of the catagenesis stage. The presence of thermogenic gas infers an effective petroleum system, which may favor the formation of gas hydrate as well as for oil and gas exploration.
\end{abstract}

(Key words: Hydrocarbon gas, Gas hydrate, Headspace gas analysis, Southwestern offshore Taiwan)

\section{INTRODUCTION}

Gas hydrates occur in sedimentary deposits under specific conditions of high pressure and low temperature present in permafrost regions and beneath the sea in outer continental margins, usually at water depths greater than about 500 meters. The estimated amount of gas in gas hydrate accumulations is believed to greatly exceed the volume of known conventional gas

\footnotetext{
${ }^{1}$ Exploration and Development Business Division, Chinese Petroleum Corporation, Taipei, Taiwan, ROC

2 Institute of Applied Geophysics, National Taiwan Ocean University, Keelung, Taiwan, ROC

${ }^{3}$ Exploration and Development Research Institute, Chinese Petroleum Corporation, Miaoli, Taiwan

* Corresponding author address: Dr. Jung-Nan Oung, Exploration and Development Business Division, Chinese Petroleum Corporation, Taipei, Taiwan, ROC; E-mail: 048607@cpc.com.tw
} 
reserves (Kvenvolden 1988). In addition, some gas hydrates may have large free gas accumulations trapped beneath them, making them more attractive to hydrocarbon exploration industries (Grauls 2001). The presence of gas hydrates in offshore continental margins has been inferred mainly by anomalous seismic reflectors known as bottom-simulating reflectors (BSR) that coincide with the predicted phase boundary at the base of the gas hydrate stability zone (GHSZ). The BSR has been mapped at depths ranging from approximately 100 to 1100 meters below the seafloor (Stoll et al. 1971). Bright spots sometimes appear, indicating free gas occurrences below the gas hydrates.

BSR has been reported in the seismic survey carried out in southwestern offshore Taiwan, indicating potential occurrences of gas hydrates (Chi et al. 1998; Schnürle et al. 1999; Liu et al. 2006). Beyond this geophysical evidence, however, any geochemical information concerning the gas system may become important to support the presence of the gas hydrates. For the purpose of understanding the gas system, especially the gas genetic origin and its significances in the potential occurrence of gas hydrates in this area, hydrocarbon gases in the seafloor sediments are investigated by using the headspace gas analysis technique. The genetic origin of hydrocarbon gas mainly involves methanogenic microbial origin which occurred in the early diagenesis stage and thermogenic origin in the catagenesis stage (Hunt 1995). The chemical and isotopic composition of the hydrocarbon gas, e.g., the methane/ethane ratio and $\delta^{13} \mathrm{C}_{\mathrm{CH}_{4}}$ are a diagnostic to the gas origin. Hydrocarbon gas of the methanogenic origin is exclusively composed of methane, which is light in carbon stable isotopic composition, usually with $\delta^{13} \mathrm{C}_{\mathrm{CH}_{4}}$ lighter than $-50 \%$. With the maturity increasing, the thermogenic gas containing methane as well as ethane and higher carbon number hydrocarbons is generated. The thermogenic methane is heavier in carbon stable isotopic value (Schoell 1984).

\section{REGIONAL GEOLOGY AND SAMPLES}

\subsection{Regional Geology}

The southwestern offshore Taiwan is situated in a subduction zone where the South China Sea plate subducts eastward beneath the Philippine Sea Plate. Mud diapirs, mud volcanoes, and faults occur as a result of the plate convergence (Sun and Liu 1993; Liu et al. 1997). Gas hydrates have been inferred and thought to be widely distributed in this area based on the occurrence of BSRs in the seismic reflection records (Chi et al. 1998; Schnürle et al. 1999; Liu et al. 2006).

\subsection{Samples}

Gravity cores were retrieved from the study area, southwestern offshore Taiwan. The scientific sounder system, SIMRAD EK500, operated at $38 \mathrm{KHz}$ was applied to survey the sea bottom surface. Numerous mounds inferring occurrences of mud volcanoes on the seafloor were detected and some of them were cored for gas analysis. Figure 1 shows a map of the study area and the stations where the cores were retrieved. The location, water depth and length of cores are given in Table 1. Each core covers about one meter of the seafloor sediments, mainly homogenous light gray mud. 


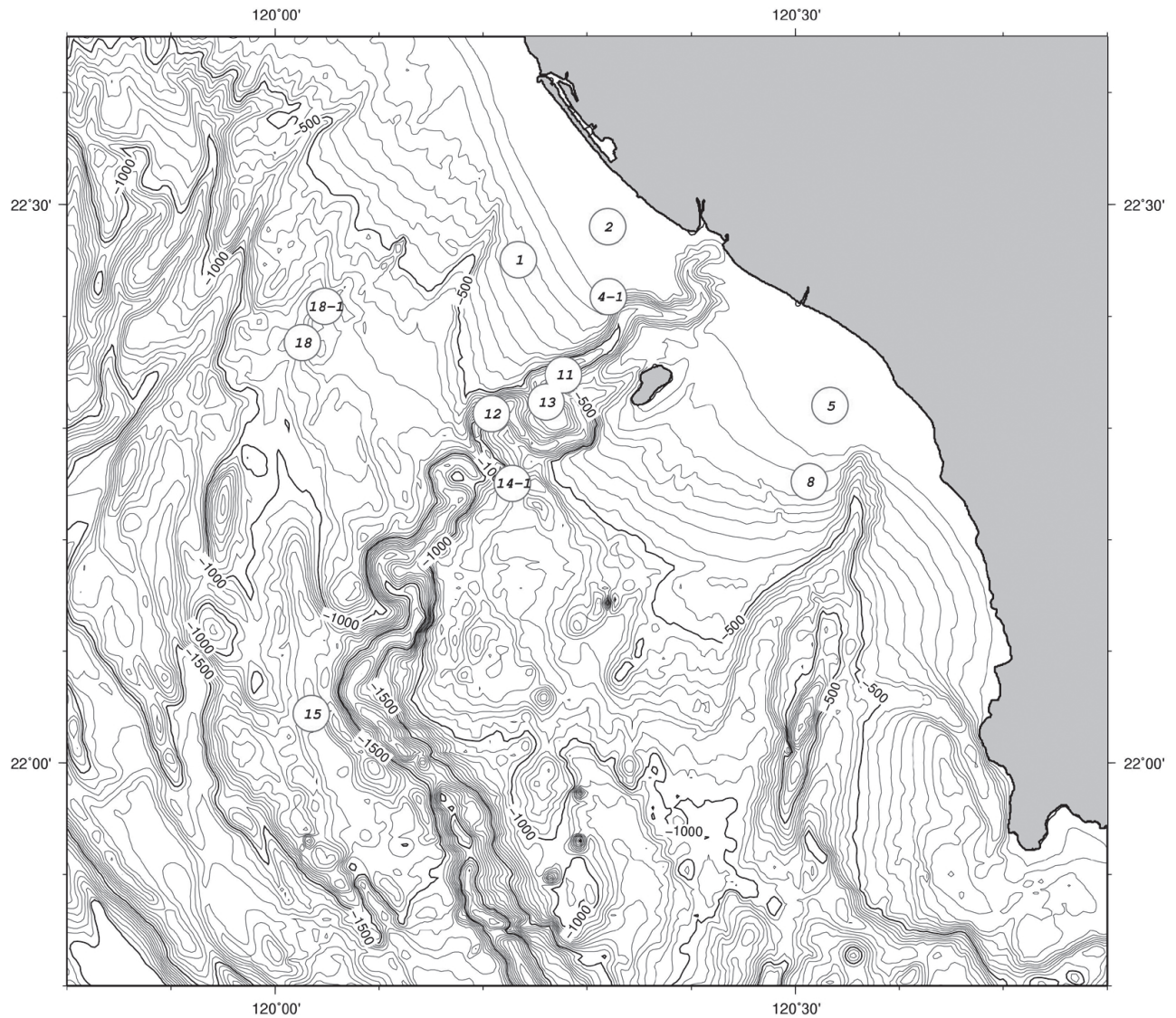

Fig. 1. Map of the southwestern offshore Taiwan. The sampling stations are indicated.

\section{HEADSPACE GAS ANALYSIS}

A core sample of about 300 grams was collected as soon as it was retrieved from the core liner. After being measured for volume, the sample was placed in 1 liter-tin can. Water was added to fill the can until $100 \mathrm{ml}$ headspace volume left. Bactericide, e.g., Zephiran Chloride, was added to prevent the bacterial alteration of the organic matter and the hydrocarbon gas. The can was then sealed and delivered to the laboratory for headspace gas analysis. Experimental procedures of the headspace gas analysis, including sample preparation and gas chromatography, are described in detail in Oung (1983). Briefly, the $1 \mathrm{ml}$ headspace gas was quantitatively analyzed by using a Varin-3400 gas chromatograph installed with a GS-alumi- 
Table 1. Sampling stations in the area of southwestern offshore Taiwan.

\begin{tabular}{|c|c|c|c|c|c|c|}
\hline Station & Longitude & Latitude & Water depth (m) & Core type & Length (cm) & Lithology \\
\hline 1 & 120.2336667 & 22.45076667 & 189 & $\mathrm{G}^{*}$ & 155 & mud \\
\hline 2 & 120.3198333 & 22.48028333 & 23 & Multi-core & & mud \\
\hline $4-1$ & 120.3206333 & 22.41743333 & 46 & G & 30 & mud \\
\hline 5 & 120.53355 & 22.32018333 & 31 & Multi-core & & mud \\
\hline 8 & 120.5137167 & 22.25226667 & 123 & G & 146 & mud \\
\hline 11 & 120.2771333 & 22.3477 & 576 & G & 120 & mud \\
\hline 12 & 120.2079333 & 22.313 & 988 & G & 101 & mud \\
\hline 13 & 120.2607167 & 22.32346667 & 535 & G & 145 & mud \\
\hline $14-1$ & 120.2281167 & 22.25056667 & 720 & G & 50 & mud \\
\hline 15 & 120.035 & 22.04426667 & 780 & G & 92 & mud \\
\hline 18 & 120.0263833 & 22.37666667 & 815 & G & 153 & mud \\
\hline $18-1$ & 120.04775 & 22.4091 & 715 & G & 20 & mud \\
\hline
\end{tabular}

*G: gravity core

num column (30 $\mathrm{m} \times 0.53 \mathrm{~mm}$ id.). A gas mixture containing methane $\left(\mathrm{C}_{1}\right)$, ethane $\left(\mathrm{C}_{2}\right)$, propane $\left(\mathrm{C}_{3}\right)$, iso- and $n$-butane $\left(\mathrm{C}_{4}\right)$, and $n$-pentane $\left(\mathrm{C}_{5}\right)$ with a known concentration was used as an external standard in gas chromatography for compound identification and quantitation.

\section{RESULTS AND DISCUSSION}

\subsection{Gas System-Gas Occurrences, Chemical Composition and Genetic Origins}

The concentration, expressed in ppm of wet sediments by volume, and chemical composition of hydrocarbon gases occurred in the seafloor sediments as measured by the headspace gas analysis technique are listed in Table 2. The gas concentrations are in the range from tens to more than $1000 \mathrm{ppm}$. What should be mentioned is that, though core samples have been collected and sealed in cans as soon as they were retrieved, the gas loss actually can't be totally avoided due to the high volatility of the gas. The original content of hydrocarbon gas in the seafloor sediments, therefore, should be much higher than what was measured in this study. The presence of gas anomalies, however, is of significance because standard procedures were taken for the sample collection, preservation and analysis. Gas anomalies are found in samples collected from stations 2, 13 and 15 with gas concentrations higher than $1000 \mathrm{ppm}$. The sample from station 13 shows a maximum at $1859 \mathrm{ppm}$. The gas anomalies may be related to the physical properties, e.g., porosity and permeability of sediments. Since all the cores analyzed are mud and may have similar physical properties, the effect of the lithology may be excluded. Gas seepages or intensive gas sources likely occur in those stations with a gas anomaly. 
Table 2. Content and chemical composition of hydrocarbon gases in seafloor sediments, southwestern offshore Taiwan.

\begin{tabular}{|c|c|c|c|c|}
\hline Station & Water Depth (m) & Sample interval $(\mathrm{cm})^{1}$ & $\mathrm{CH}_{4}(\mathrm{ppm}$ by volume) & Compositional characteristics \\
\hline 1 & 189 & $30 \sim 50$ & 386 & $\mathrm{C}_{1}$ only, $\mathrm{C}_{2}$ below detection limit ${ }^{2}$ \\
\hline 1 & 189 & $80 \sim 90$ & 129 & $\mathrm{C}_{1}-\mathrm{C}_{2}, \mathrm{C}_{2}$ in $\operatorname{trace}^{3}$ \\
\hline 2 & 23 & $0 \sim 10$ & 1604 & $\mathrm{C}_{1}$ only, $\mathrm{C}_{2}$ below detection limit \\
\hline $4-1$ & 46 & $0 \sim 10$ & 447 & $\mathrm{C}_{1}$ only, $\mathrm{C}_{2}$ below detection limit \\
\hline $4-1$ & 46 & $21 \sim 31$ & 89 & $\mathrm{C}_{1}-\mathrm{C}_{2}, \mathrm{C}_{2}$ in trace \\
\hline 5 & 31 & $0 \sim 15$ & 115 & $\mathrm{C}_{1}-\mathrm{C}_{2}, \mathrm{C}_{2}$ in trace \\
\hline 8 & 123 & $20 \sim 30$ & 210 & $\mathrm{C}_{1}$ only, $\mathrm{C}_{2}$ below detection limit \\
\hline 8 & 123 & $100 \sim 110$ & 34 & $\mathrm{C}_{1}-\mathrm{C}_{2}, \mathrm{C}_{2}$ in trace \\
\hline 11 & 576 & $40 \sim 50$ & 73 & $\mathrm{C}_{1}-\mathrm{C}_{2}, \mathrm{C}_{2}$ in trace \\
\hline 12 & 988 & $30 \sim 40$ & 48 & $\mathrm{C}_{1}-\mathrm{C}_{2}, \mathrm{C}_{2}$ in trace \\
\hline 13 & 535 & $30 \sim 40$ & 1859 & $\mathrm{C}_{1}$ only, $\mathrm{C}_{2}$ below detection limit \\
\hline 13 & 535 & $70 \sim 80$ & 435 & $\mathrm{C}_{1}$ only, $\mathrm{C}_{2}$ below detection limit \\
\hline 13 & 535 & $110 \sim 120$ & 67 & $\mathrm{C}_{1}-\mathrm{C}_{2}, \mathrm{C}_{2}$ in trace \\
\hline $14-1$ & 720 & $0 \sim 10$ & 57 & $\mathrm{C}_{1}-\mathrm{C}_{2}, \mathrm{C}_{2}$ in trace \\
\hline $14-1$ & 720 & $40 \sim 50$ & 163 & $\mathrm{C}_{1}-\mathrm{C}_{2}, \mathrm{C}_{2}$ in trace \\
\hline 15 & 780 & $20 \sim 30$ & 1624 & $\mathrm{C}_{1}-\mathrm{C}_{5}, \mathrm{C}_{2}{ }^{+}$significant ${ }^{4}$ \\
\hline 18 & 815 & $80 \sim 90$ & 59 & $\mathrm{C}_{1}-\mathrm{C}_{2}, \mathrm{C}_{2}$ in trace \\
\hline $18-1$ & 715 & $0 \sim 20$ & 270 & $\mathrm{C}_{1}-\mathrm{C}_{2}, \mathrm{C}_{2}$ in trace \\
\hline \multicolumn{5}{|c|}{${ }^{1}$ Depth below seafloor } \\
\hline $\begin{array}{l}{ }^{2} \mathrm{C}_{2}^{+} \text {peak } \\
{ }^{3} \mathrm{C}_{2}^{+} \text {cont } \\
{ }^{4} \mathrm{C}_{2}^{+} \text {arou }\end{array}$ & $\begin{array}{l}\text { e not distinguished ir } \\
\text { is estimated less than } \\
7 \%\end{array}$ & $\begin{array}{l}\text { omatograms } \\
\%\end{array}$ & & \\
\hline
\end{tabular}

With regard to the chemical composition, methane was dominant in all samples analyzed. The hydrocarbon gases with higher carbon number, i.e., the so-called $\mathrm{C}_{2}^{+}$gases including ethane, propane, iso- and $n$ - (normal) butanes, are detected only in some samples and usually in trace, except for the sample from station 15 which shows $\mathrm{C}_{2}^{+}$concentration as high as $17 \%$. Typical gas chromatograms of hydrocarbon gases with different chemical compositions are shown in Fig. 2.

The $\mathrm{C}_{2}^{+}$content is used to distinguish the origin of the hydrocarbon gas. The sample from station 15 containing $\mathrm{C}_{2}^{+}$is regarded as thermogenic gas generated from mature sediments or as a mixture of thermogenic gas and microbial gas. Hydrocarbon gas composition of this sample is methane: $82.3 \%$, ethane: $9.6 \%$, propane: $3.8 \%$, iso-butane: $0.7 \%, n$-butane: $1.6 \%$, iso-pentane: $0.8 \%$, and $n$-pentane: $1.3 \%$. The presence of a significant amount of ethane, propane, butanes and pentanes strongly indicates its thermogenic origin. Both ratios of isobutane $/ n$-butane and iso-pentane $/ n$-pentane are less than 1 . Unsaturated hydrocarbons, e.g., ethene and propene, are not detected, again in agreement with its generation in the catagenesis stage. The samples depleted in $\mathrm{C}_{2}^{+}$, e.g., samples from stations $1,2,4-1,8$, and 13 are assigned as microbial gas generated in the sediment of the early diagenesis stage, though the possibility of thermogenic gas can't be totally excluded because the $\mathrm{C}_{2}{ }^{+}$hydrocarbons tend to dissipate during long distance migration. Isotopic composition of these samples was not mea- 


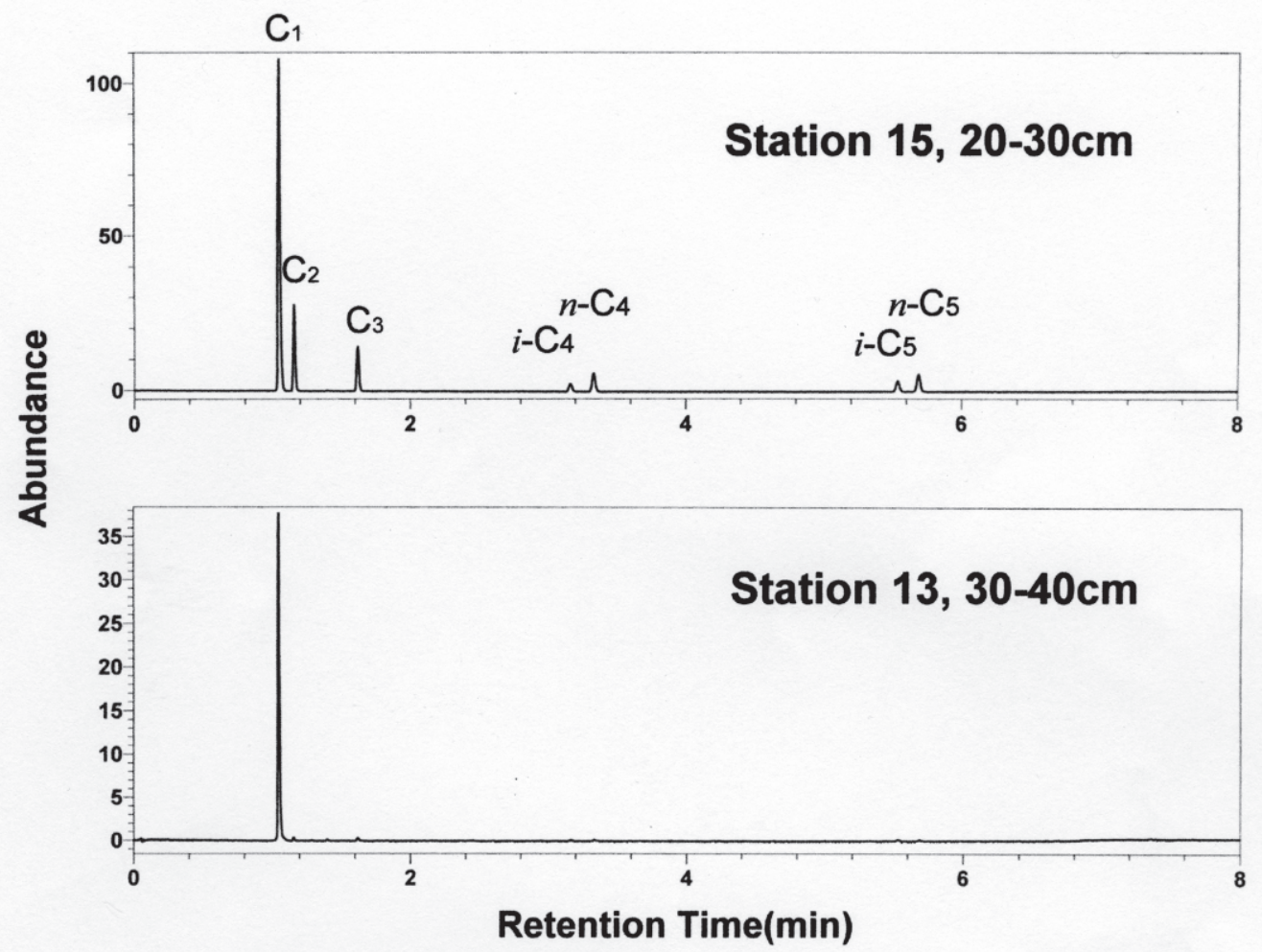

Fig. 2. Typical gas chromatograms of natural gases with different chemical composition. The gas from station 15 contains a significant amount of $\mathrm{C}_{2}^{+}$, inferring its thermogenic origin (top). The gas of station 13 is of microbial origin (bottom).

sured due to a low gas concentration. However, samples of depleted in $\mathrm{C}_{2}^{+}$hydrocarbons from an adjacent area show a light $\delta \mathrm{C}^{13}$ value (Chuang et al. 2006) supporting the microbial origin of the samples depleted in $\mathrm{C}_{2}^{+}$in this study.

It is concluded that gases of both microbial and thermogenic origins are encountered in this study area, with the microbial gas widely distributed. High methane concentrations are also encountered in the adjacent area (Chao and You 2006; Chen and Tseng 2006; Chuang et al. 2006; Huang et al. 2006; Lin et al. 2006; Yang et al. 2006). This gas system may be extended from onshore southwestern Taiwan where microbial gas and thermogenic gas have been discovered. Hydrocarbon gases composed of pure methane are frequently encountered in the Pleistocene alluvial deposits in the Chianan plain of southwestern Taiwan when drilling water wells (Hsu 1984). Chemical composition as well as carbon stable isotopic composition 
confirms their microbial origin (Lu and Lin 1984). An economic production of microbial gas from the Hsinying gas field and a recent discovery of microbial gas by the Chinese Petroleum Corporation from Lung-Tien, both in Tainan County, indicate the microbial gas potential in this area (Chen et al. 2004). Thermogenic gas is found to be associated with mud volcanoes onshore. Mud volcanoes occur along fault zones in onshore southern Taiwan (Shih 1967; Yang et al. 2004). Natural gas samples collected from several mud volcanoes, e.g., the Wandan mud volcano in Pingtong County, were analyzed and show $\mathrm{C}_{2}^{+}$concentrations of around $3 \%$, indicating that thermogenic gas is involved (Oung, unpublished data).

\subsection{Implications of the Natural Gas System in Gas Hydrate Occurrences}

Gas hydrate occurrences mainly depend on the physical conditions required for the formation and preservation of gas hydrates, e.g., formation temperature and pore pressure, and the availability of gas and water. Studies on physical conditions, mainly heat flow, have been carried out to determine the depth interval of GHSZ in this area (Shyu et al. 1998; Shyu et al. 2006). The gas system and its implications to the gas hydrate occurrences are discussed below.

\subsubsection{Gas Source and Gas Hydrate Distribution}

This survey reveals the occurrence of gas anomalies of both microbial and thermogenic origins in the seafloor sediments, inferring that the potential gas hydrate in the study area may have multiple gas origins, with microbial gas more widely occurring than thermogenic gases. The microbial methane is generated in immature sediments containing high organic content by methanogenic archaea. The study area is situated in the accretionary prism east of the Manila Trench (Sun and Liu 1993; Liu et al. 1997). Sediments derived from the Western Foothill and Central Mountain Range of southern Taiwan was deposited with a high sedimentation rate. The organic matter is therefore well preserved. Samples collected from the study area have been analyzed for total organic carbon content and show $0.5-0.6 \%$ on average (Lee 1994; Lee 2003). These sedimentary rocks may serve as regional potential source rocks for the microbial gas.

The thermogenic gas is generated in mature sediments and the $\mathrm{C}_{2}^{+}$concentration usually increases along with increasing maturity before getting into the metagenesis stage (Hunt 1995). It is inferred that this thermogenic gas with $\mathrm{C}_{2}^{+}$concentration of $17 \%$ from station 15 is generated from the sediments in the oil window based on the relationship between $\mathrm{C}_{2}^{+}$concentration and maturation level resulting from the cutting gas analysis on the Tertiary formations encountered by oil exploration wells in offshore Taiwan (Oung 1983). Although the source rocks of the thermogenic gas remain to be determined and evaluated, an effective petroleum system with active gas generation is indicated in this area and may favor the formation of gas hydrate as well as oil and gas exploration.

Total gas concentrations must reach the critical amounts necessary for the formation of gas hydrates. Therefore, geologic controls on gas migration such as rock permeability and the nature of faulting are required for the gas to be delivered to the GHSZ. Considering the gas source and migration path, it is believed that methane hydrates more likely occur in the rela- 
tively permeable sediments in the GHSZ as a stratigraphic accumulation (Milkov and Sassen 2002). Whereas the gas hydrate attributed to thermogenic gas is expected to distribute over the faults acting as an efficient migration pathway for thermogenic gas vertical migration. Gas hydrates are also expected to occur around the mud volcanoes in this area. Relations between gas hydrates and mud volcanoes have been reported (Hedberg 1974; Reed et al. 1990; Milkov and Sassen 2002). Mud volcanoes that occur in the southwestern offshore Taiwan (Chiu et al. 2006) are proposed as a consequence of gas hydrate dissociation caused by the heat fluids derived from the deep (Yeh et al. 2003).

\subsubsection{Gas Hydrate Thickness and Structure}

The depth interval of the GHSZ is affected by the chemical composition of the gas involved. Generally the stability zone of the gas hydrate containing ethane and higher molecular hydrocarbon gases is thicker than that of pure methane hydrate (Holder et al. 1987; Milkov and Sassen 2000). Since both microbial methane and thermogenic gases are supposed to be involved in the gas hydrates in this area, the GHSZ may be thicker than when only pure microbial methane involved. The gas hydrates containing $\mathrm{C}_{2}^{+}$are expected to be encountered in shallower water depth and extended to deeper burial depths than methane hydrates.

The structures of gas hydrates are related to the gases involved. Gas hydrates usually form three crystal structures, i.e., structures I, II and H (Sloan 1998). Structure I is usually related to small gas molecules, e.g., methane, ethane, $\mathrm{H}_{2} \mathrm{~S}$, and $\mathrm{CO}_{2}$. Structure II is related to the higher gas molecules such as propane and iso-butane (Makogon 1981). Structure H specifically occurs when big molecules like adamantane, gasoline-range hydrocarbons and naphthalene ingredients are involved. It is inferred that the potential gas hydrates occurred in the southwestern offshore Taiwan may mainly have structure I and structure II based upon the chemical composition revealed in this study. Structure H, however, is not totally excluded since thermogenic gas containing pentane has been detected.

\section{CONCLUSION}

This survey reveals the occurrences of gas anomalies of both microbial and thermogenic origins in the seafloor sediments, inferring that potential gas hydrate in the study area may have multiple gas origins, with microbial gas more widely distributed than thermogenic gases. An effective petroleum system with active thermogenic gas generation is indicated and may favor the formation of gas hydrate as well as oil and gas exploration. The occurrence of hydrocarbon gas anomalies, mud volcanoes and active faults, combined with the presence of BSRs, strongly illustrates the potential existence of natural gas hydrates in this area. Gas hydrates of microbial methane more likely occur in the relatively permeable sediments in the GHSZ, whereas the gas hydrate attributed to the thermogenic gas is expected to be distributed over the faults acting as an efficient vertical migration pathway.

Acknowledgements The core samples were retrieved by the R/V Ocean Researcher III cruise. We highly appreciate Chen, D. C. of EDRI, CPC for his assistance in the headspace gas analysis. 
We also like to thank Dr. Amane Waseda and an anonymous reviewer for their constructive and valuable comments to this manuscript. This study is supported by the National Science Council.

\section{REFERENCES}

Chao, H. C., and C. F. You, 2006: Distribution of B, Cl and their isotopes in pore waters separated from gas hydrate potential areas, offshore southwestern Taiwan. Terr. Atmos. Ocean. Sci., 17, 961-979.

Chen, C. T. A., and H. C. Tseng, 2006: Abnormally high $\mathrm{CH}_{4}$ concentrations in seawater at mid-depths on the continental slopes of the northern South China Sea. Terr. Atmos. Ocean. Sci., 17, 951-959.

Chen, T. S., W. C. Shih, C. C. Chern, H. C. Lin, and H. L. Yu, 2004: A new discovered shallow biogenic gas field in Lung-Tien, Tainan. Conference proceedings of International Workshop on Gas Hydrate Exploration and Exploitation, Taipei, November 8 - 9, $2004,48$.

Chi, W. C., D. L. Reed, C. S. Liu, and N. Lundberg, 1998: Distribution of the bottom-simulating reflector in the offshore Taiwan Collision Zone. Terr. Atmos. Ocean. Sci., 9, 779794.

Chiu, J. K., W. H. Tseng, and C. S. Liu, 2006: Distribution of gassy sediments and mud volcanoes offshore southwestern Taiwan. Terr. Atmos. Ocean. Sci., 17, 703-722.

Chuang, P. C., T. F. Yang, S. Lin, H. F. Lee, T. F. Lan, W. L. Hong, C. S. Liu, J. C. Chen, and Y. Wang, 2006: Extremely high methane concentration in bottom water and cored sediments from offshore southwestern Taiwan. Terr. Atmos. Ocean. Sci., 17, 903-920.

Grauls, D., 2001: Gas hydrates: importance and applications in petroleum exploration. Mar. Petrol. Geol., 18, 519-523.

Hedberg, D. H., 1974: Relation of methane generation to undercompacted shales, shale diapirs, and mud volcanoes. AAPG Bull., 58, 661-673.

Holder, G. D., R. D. Malone, and W. F. Lawson, 1987: Effects of gas composition and geothermal properties on the thickness and depth of natural-gas-hydrate zone. J. Petrol. Technol., 39, 1147-1152.

Hsu, L. M., 1984: Pleistocene formation with dissolved-in-water type gas in the Chianan plain, Taiwan. Petrol. Geol. Taiwan, 20, 199-213.

Huang, C. Y., C. W. Chien, M. Zhao, H. C. Li, and Y. Iizuka, 2006: Geological study of active cold seeps in the syn-collision accretionary prism Kaoping slope off SW Taiwan. Terr. Atmos. Ocean. Sci., 17, 679-702.

Hunt, J. M., 1995: Petroleum Geochemistry and Geology. $2^{\text {nd }}$ Ed., New York, Freeman, 743 pp.

Kvenvolden, K. A., 1988: Methane hydrate - A major reservoir of carbon in the shallow geosphere? Chem. Geol., 71, 41-51.

Lee, C. Y., 2003: Preliminary studies on the relations between mud diapir and gas hydrates, southwestern offshore Taiwan. Master Thesis, Nat. Taiwan Ocean Univ., Taiwan, 79 pp. (in Chinese) 
Lee, Z. H., 1994: A preliminary geochemical study of organic carbon and reduced sulfur in the Plio-Pleistocene mudstone in southwestern Taiwan and marine sediments off SW Taiwan. Master Thesis, Nat. Taiwan Univ., Taiwan, 102 pp. (in Chinese)

Lin, S., W. C. Hsieh, Y. C. Lim, T. F. Yang, C. S. Liu, and Y. Wang, 2006: Methane migration and its influence on sulfate reduction in the Good Weather Ridge region, South China Sea continental margin sediments. Terr. Atmos. Ocean. Sci., 17, 883-902.

Liu, C. S., I. L. Huang, and L. S. Teng, 1997: Structural features off southwestern Taiwan. Mar. Geol., 137, 305-319.

Liu, C. S., P. Schnürle, Y. Wang, S. H. Chung, S. C. Chen, and T. H. Hsiuan, 2006: Distribution and characters of gas hydrate offshore of southwestern Taiwan. Terr. Atmos. Ocean. Sci., 17, 615-644.

Lu, D. L., and J. T. Lin, 1984: The measurement and its preliminary interpretation of carbon and hydrogen isotopes of natural gas in north-western Taiwan. Report on Exploration and Production Research, EDRI, CPC, 7, 173-187. (in Chinese)

Makogon, Y. F., 1981: Hydrates of Natural Gas. Tulsa, Penn Well Publishing, 237 pp.

Milkov, A. V., and R. Sassen, 2000: Thickness of the gas hydrate stability zone, Gulf of Mexico continental slope. Mar. Petrol. Geol., 17, 981-991.

Milkov, A. V. and R. Sassen, 2002: Economic geology of offshore gas hydrate accumulations and provinces. Mar. Petrol. Geol., 19, 1-11.

Oung, J. N., 1983: Analysis of light hydrocarbons from cuttings and its application in petroleum geochemistry. Petroleum Drilling Engineering, Chin. Petrol. Inst., 24, 207-221. (in Chinese)

Reed, D. L., E. A. Silver, J. E. Tagudin, T. H. Shipley, and P. Vrolijk, 1990: Relations between mud volcanoes, thrust deformation, slope sedimentation, and gas hydrate, offshore north Panama. Mar. Petrol. Geol., 7, 44-54.

Schnürle, P., T. H. Hsiuan, and C. S. Liu, 1999: Constrains on free gas and gas hydrate bearing sediments from multi-channel seismic data, offshore southwestern Taiwan. Petrol. Geol. Taiwan, 33, 21-42.

Schoell, M., 1984: Recent advances in petroleum isotope geochemistry. Org. Geochem., 6, 645-663.

Shih, T. T., 1967: A survey of the active mud volcanoes in Taiwan and a study of their types and character of the mud. Petrol. Geol. Taiwan, 5, 259-311.

Shyu, C. T., S. K. Hsu, and C. S. Liu, 1998: Heat flows off southwest Taiwan: measurements over mud diapirs and estimated from bottom simulating reflectors. Terr. Atmos. Ocean. Sci., 9, 795-812.

Shyu, C. T., Y. J. Chen, S. T. Chiang, and C. S. Liu, 2006: Heat flow measurements over bottom simulating reflectors, offshore southwestern Taiwan. Terr. Atmos. Ocean. Sci., 17, 845-869.

Sloan, E. D., 1998: Clathrate Hydrates of Natural Gases. $2^{\text {nd }}$ Ed., New York, Marcel Dekker Inc., $705 \mathrm{pp}$.

Stoll, R. D., J. Ewing, and G. M. Bryan, 1971: Anomalous wave velocities in sediments containing gas hydrates. J. Geophys. Res., 76, 2090-2094.

Sun, S. C., and C. S. Liu, 1993: Mud diapirs and submarine channel deposits in offshore 
Kaohsiung-Hengchun, southwest Taiwan. Petrol. Geol. Taiwan, 28, 1-14.

Yang, T. F., G. H. Yeh, C. C. Fu, C. C. Wang, T. F. Lan, H. F. Lee, C. H. Chen, V. Walia, and Q. C. Sung, 2004: Composition and exhalation flux of gases from mud volcanoes in Taiwan. Environ. Geol., 46, 1003-1011.

Yang, T. F., P. C. Chuang, S. Lin, J. C. Chen, Y. Wang, and S. H. Chung, 2006: Methane venting in gas hydrate potential area offshore of SW Taiwan: evidence of gas analysis of water column samples. Terr. Atmos. Ocean. Sci., 17, 933-950.

Yeh, G. H., T. F. Yang, J. C. Chen, Y. G. Chen, C. S. Liu, and C. F. You, 2003: Geochemical evidence for offshore gas hydrates genetically related to on-land mud volcanoes in SW Taiwan. Abstract to XVI INQUA congress, Reno, USA, July 23 - 30.

Oung, J. N., C. Y. Lee, C. S. Lee, and C. L. Kuo, 2006: Geochemical study on hydrocarbon gases in seafloor sediments, southwestern offshore Taiwan - implications in the potential occurrence of gas hydrates. Terr. Atmos. Ocean. Sci., 17, 921-931. 